\title{
Strategy For A/M Area Production Wells
}

by

D. G. Jackson

Westinghouse Savannah River Company

Savannah River Site

Aiken, South Carolina 29808

B. B. Looney

C. L. Bergren

D. G. Wells

B. A. Beavers

DOE Contract No. DE-AC09-89SR18035

This paper was prepared in connection with work done under the above contract number with the U.S. Department of Energy. By acceptance of this paper, the publisher and/or recipient acknowledges the U.S. Government's right to retain a nonexclusive, royalty-free license in and to any copyright covering this paper, along with the right to reproduce and to authorize others to reproduce all or part of the copyrighted paper. 


\section{DISCLAIMER}

This report was prepared as an account of work sponsored by an agency of the United States Government. Neither the United States Government nor any agency thereof, nor any of their employees, makes any warranty, express or implied, or assumes any legal liability or responsibility for the accuracy, completeness, or usefulness of any information, apparatus, product, or process disclosed, or represents that its use would not infringe privately owned rights. Reference herein to any specific commercial product, process, or service by trade name, trademark, manufacturer, or otherwise does not necessarily constitute or imply its endorsement, recommendation, or favoring by the United States Government or any agency thereof. The views and opinions of authors expressed herein do not necessarily state or reflect those of the United States Government or any agency thereof.

This report has been reproduced directly from the best available copy.

Available to DOE and DOE contractors from the Office of Scientific and Technical Information, P. O. Box 62, Oak Ridge, TN 37831; prices available from (423) 576-8401.

Available to the public from the National Technical Information Service, U. S. Department of Commerce, 5285 Port Royal Road, Springfield, VA 22161. 


\section{DISCLAIMER}

Portions of this document may be illegible electronic image products. Images are produced from the best available original document. 


\section{Strategy for A/M Area Production Well Modifications (U)}

February 29, 1996

Dennis G. Jackson

Brian B. Looney

Chris L. Bergren

Daniel G. Wells

Buford A. Beavers

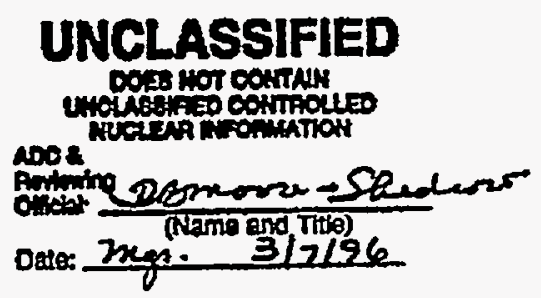

Westinghouse Savannah River Company

Savannah River Site

Aiken, South Carolina 29808

Prepared for the United States Department of Energy under Contract No. DE-AC09-89SR18035.

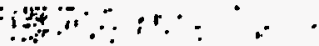

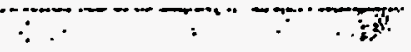




Disclaimer
This report was prepared by Westinghouse Savannah River Company (WSRC) for the United States
Department of Energy (DOE) under Contract No. DE-AC09-89SR18035 and is an account of work
performed under that contract. Every effort was made by the authors to assure the accuracy of the contents
and interpretation. However, neither the DOE, nor WSRC, nor any of their employees makes any
warranty, express or implied, or assumes any legal liability or responsibility for the accuracy,
completeness, or usefulness of any information, apparatus, or product, or process disclosed herein, or
represents that its use will not infringe privately owned rights. Reference herein to any specific
commercial product, process, or service by trademark, name, manufacturer, or otherwise does not
necessarily constitute or imply endorsement, recommendation, or favoring of same by the United States
Govemment or any, agency thereof. The views and opinions of the authors expressed herein do not
necessarily state or reflect those of the United States Government or any agency thereof.




\section{Strategy for A/M Area Production Well Modifications (U)}

February 29, 1996

Dennis G. Jackson

Brian B. Looney

Chris L. Bergren

Daniel G. Wells

Buford A. Beavers

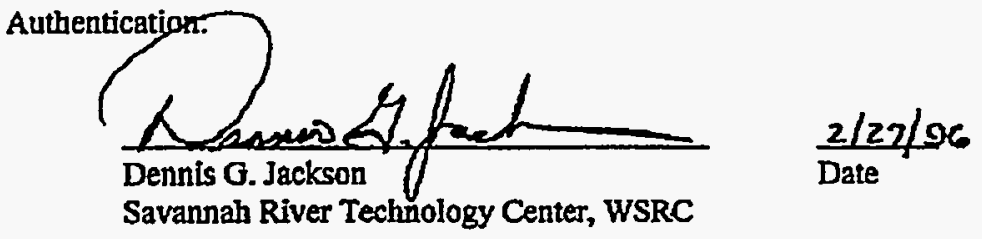

Westinghouse Savannah River Company

Savannah River Site

Aiken, South Carolina 29808

Prepared for the United States Department of Energy under Contract No. DE-AC09-89SR18035. 


\section{Executive Summary}

Savannah River Site personnel are planning a two phase program in order to significantly reduce the amount of dissolved chlorinated solvents that are being transported to the McQueen Branch Aquifer via the wellbore and gravel pack zones of the A/M Area production well system. In Phase I of the program a commercially available inftatable packer and check valve assembly will be installed inside the casing at the altitude of the McQueen Branch Confining Unit. This immediate, short term solution will eliminate the majority of the contaminant mass that is moving downward through the wellbore of the $A / M$ Area production weils. During the packer bustallation process several pre- and post- testing activities are planned to aid SRS investigators in understanding the dynamics of the flow conditions and effectiveness of the installed assembly.

The second phase of the program will addzess the small amount of contaminant mass that is moving downward through the continuons gravel pack of the production wells. The investigative data obtained during Phase I of this program will be beneficial for developing plans and appropriate actions for the Phase II activities. Site persomel are currenty evaluating various options, i.e. casing perforation with grout injection or partial well abandonmem, to eliminate the downward flow in the gravel pack at the altitude of the McQueen Branch Confining Zone.

In addressing potential remediation actions for the dissolved solvents in the Cretaceous sediments, due to the limited vertical extent of the phume and the size, any remediation program should incorporate carefully located wells screened vertically within the plume trajectory. This optimizing approach will minimize water treatment and pumping costs and moximize the amount of contaminant removal. Flow and contaminant transport modeling scenarios are currently being developed to address the Cretaceous sediments. These efforts involve incorporating the available characterization data and the results of previous modeling work to more precisely define the extent and magnitude of this plume. SRS proposes incorporating depth discrete sampling during any future characterization effort to optimize any proposed remediation system. Finally, by using a fully three-dimensional model rather than the traditional quasithree dimensional methods an efficient remediation system can be developed. 


\section{Table of Contents}

Executive Summary ______ ii

Table of Contents ___ iii

List of Figures ___ iv

List of Tables _ iv

1.0 Background ___ I

1.1 A/M Area Production Well System __ 1

1.2 Hydrostratigraphy of the A/M Area

1.3 Contaminants in the Cretaceous Sediments ___ 3

2.0 Modifications to Production Well System___

2.1 Phase I Activities 9

2.1.1 Pre-Installation Testing

2.1.1.1 Downhole Video Survey

2.1.1.2 Packer Testing of Upper Casing

2,1.1.3 Profile of Vertical Flowrates

2.1.1.4 Water Sample and Anahysis from Specific Horizons ___ 10

2.1.2 Installation Details

2.1.2.1 Production Well 905-15A 11

2.1.2.2 Production Well 905-20A___ 11

2.1.2.3 Production Well 905-31A_______ 11

2.1.2.4 Production Well 905-53A___ 11

2.1.2.5 Production Well 905-82A__ 11

2.1.3 Post-Installation Testing ___ 11

2.1.3.1 Vertical Flowrate above Check Valve ___ 11

2.1.3.2 Production Capacity Tests ___ 12

2.1.4 Periodic Maintenance of Packer Assemblies ___ 12

2.2 Phase II Activities___ 12

2.3 Proposed Schedule 12

3.0 Long Term Strategies for Cretaceous Aquifers ___ 14

4.0 Summary __.

5.0 References __ 14 


\section{List of Figures}

Figure \#1: Production Wells, Crouch Branch Monitoring Wells, and Soil Borings in the A/M Area.

Figure \#2: Configuration and Construction Details for the AM Area Production Wells.

Figure \#3: Hydrostratigraphy of the A/M Area.

Figure \#4: Schematic Representation of a Typical Packer and Check Valve Assembly.

\section{List of Tables}

Table \#1: Historical Summary of Chlorocarton Concentrations in A/M Area Production Wells Table \#2: Summary of A/M Area Production Well Construction Details. 


\subsection{Background}

The A/M-Area is located in the northem section of the Savannah River Site (SRS) and consists of those facilities that fabricated reactor fuel and target assemblies for the SRS reactors (M-Area), laboratory facilities (SRTC, formally SRL), and administrative and support facilities (A-Area). Operations at these and other facilities within the $A M M$ Area resulted in the release of chlorinated solvents, primarily trichloroethylene (TCE), tetrachloroethylene (PCE) and $1,1,1-$ trichloroethane $(1,1,1-T C A)$ to the subsurface. These releases have resulted in the contamination of the soil and groundwater within the area. The first indication of solvent contamination in the Crouch Branch Aquifer occurred in July of 1981 when a water sample from produetion well $905-53 \mathrm{~A}$ indicated TCE contamination at $10 \mathrm{ppb}$, with subsequent indications from production wells 905-20A and 905-31A. Trace amounts, less than the current drinking water standards, have also been measured in production wells 905-68 A and 905-82A. To aid in characterizing the extent of the contamination in the Crouch Branch several monitoring wells have been installed and multiple bulk soil samples collected and analyzed for volatile organics using a headspace analysis procedure developed at the Savannah River Site (Looney et. al., 1993). Figure \#1 presents the location of the production weils, Cretaceous monitoring wells, and Cretaceous soil borings in the AM Area.

\subsection{A/M Area Production Well System}

The production water well system in the AMM Area consists of a series of wells that are used to provide domestic and process water for operations in the AMM Area of the Savannah River Site. The production well system was installed in the early 1950's during the initial construction phases of the plant. The system originally consisted of wells 905-15A, 905-20A, 905-31A, 905-53A, and 905-82A. This system was slightly expanded in the mid-1960's when well 905-68A was installed to provide a backup source of water for the Site's Emergency Response Center. During this same period, production well 905-15A was removed from service and placed in a standby status, followed in November of 1988 by production well 905-31A. Of the original wells, production wells 905-20A, 905-53A, 905-68A, and 905-82A are the only wells that are operated regularly as a source of domestic and process water. With the exception of 905-15A and 905-68A, the AM Area production wells are installed with multiple screen zones in both the Crouch Branch and McQueen Branch Aquifer Zones, formally known as the upper and lower Tuscaloosa, which is part of the regional hydrologic system that is used for both as an on-site and an off-site source of domestic and process water.

The first indication of solvent contamination in the production well system occurred in July of 1981 when a water sample from production well 905-53A indicated TCE contamination at $10 \mathrm{ppb}$ (Horvath, 1988). Since this discovery, dissolved solvents have also been identified in water samples from production wells 905-20A and 905-31A. Trace amounts, less than the current drinking water standards, have also been measured in wells 905-68A and 905-82A. A summary of the average amount of chlorocarbon in the A/M Area Production Welts has been compiled from Annual Environmental Reports and is presented in Table \#1. As indicated from this data, the chlorocarbon concentrations in production wells 905-20A and 905-53A have steadily increased since 1982 . As a result of the increased levels of chlorocarbon, primarily TCE, in these two wells there application has been exclusively limited as a process water resource. Other than during 1990, measurable quantities of chlorocarbons have never been detected in samples from the domestic water wells 905-68A and 905-82A. It is sensible to note that the data presented in Table \#1 is representative of the level of contamination that occurs as a result of pumping from the entire screen section of an individual production well, which ranges from 75 to 155 feet of total screen length with over 200 feet of continuous gravel pack. It is erroneous to conclude from this data that the Crouch Branch and McQueen Branch Aquifers beneath the A/M Area are uniformly contaminated across this entire vertical extent of the production well screens. As discussed in later sections, examination of the diserete headspace data obtained during recent characterization efforts indicates that the contaminant plume is localized along

1

Prepared for the United States Department of Energy under Contract No. DE-AC09-89SR18035. 
a thin, distinct horizon within the Crouch Branch Aquifer Zone. During well operation, the groundwater plume containing high contaminant concentrations is mixed with the water from the uncontaminated sections of the aquifer to produce a "bulk" contaminant level. This "bulk" contaminant level represents the average concentration as a result of mixing across the entiro screened interval and is the data that is presented in Table \#1.

The early production wells in the A/M Area were installed with multiple screen zones in the Crouch Branch and McQueen Branch Aquifer Zones, formally referred to as the upper and lower Tuscaloosa. By examining available records that document the as-built conditions of the production wells in the AM Area, several general comments regarding the method of construction can be formed. The production wells are constructed in two sections, a large diameter upper section that is grouted into the tertiary sediments and a smaller diameter lower section that penetrates the deeper Crouch Branch and McQueen Branch Aquifers. The as-built records indicate that the upper sections were generally installed to and firmly grouted into the "lower clay" zone of the Crouch Branch Confining Unit, formally referred to as the Ellenton clays. Once below this clay zone, the bore for the lower section was under-reamed and a series of small diameter screens and casing installed. After installation of the lower section, a continuous gravel pack was installed along the length of the lower section from the maximum depth to the upper most screen zone. The screen zones are connected by this continuous gravel pack. The available records do not give any indication that the integrity of the McQueen Brarich Confining Unit was restored after the continuous gravel pack was installed. Figure \#2 presents a schematic representation of the configuration of the A/M Area production wells along with the corresponding elevations of the Crouch Branch and the MeQueen Branch Confining Units. Table \#2 presents the specific design features of each of the production wells.

\subsection{Hydrostratigraphy of the AMM Area}

The hydrostratigraphy in AM Area consists of three aquifer zones, which in descending order are the Steed Pond Aquifer, the Crouch Branch Aquifer, and the McQueen Branch Aquifer (Lewis and Aadland, 1994, Aadland et. al. 1995). Figure \#3 presents the discussed hydrostratigraphy in a schematic representation. The Steed Pond Aquifer is comprised of the M-Area Aquifer Zone, the Green Clay Confining Zone, and the Lost Lake Aquifer Zone. Towards the northem boundary of the site, the Green Clay Confining Zone thins and disappears. In this region the M-Area Aquifer Zone coalesces with the Lost Lake Aquifer Zone and is referred to solely as the Steed Pond Aquifer. The Steed Pond Aquifer is separated from the Crouch Branch Aquifer by the Crouch Branch Confining Unit. This confining unit is represented by three distinct zones. These zones in descending order are the "Upper Clay" Confining Zone, the "Middle Sand" Aquifer Zone, and the "Lower Clay" Confining Zone. Beneath the Crouch Branch Confining Unit lies the Crouch Branch Aquifer. This unit is the principal water-producing aquifer at SRS and is the deepest unic that is penetrated with the current $A M M$ Area monitoring well system. Within the vicinity of the AMM Area the unit is approximately 300 feet thick having relatively high transmissivity values due to the coarse sand and low clay content of the aquifer. Separating the Crouch Branch Aquifer from the lower McQueen Branch Aquifer is the McQueen Branch Confining Unit. In the AM Area the MCQueen Branch Confining Unit consists of an approximately 35-foot thick bed of clay and silty clay. The McQueen Branch Aquifer is approximately 180-feet thick in the A/M Area, and consists of medium to very coarse-grained, very poorly to moderately sorted, and slightly to moderately indurated pebbly sands. The hydraulic heads in the Crouch Branch Aquifer are slightly higher in the AM Area (approximately 710 feet) than in the McQueen Branch Aquifer. This downward head difference results in the downward migration of contaminants across the McQueen Branch Confining Unit at those locations were the confining zone is breached by the production wells.

In April of 1983 a pumping test was performed to determine the hydraulic characteristics of the Crouch Branch and McQueen Branch Aquifers (Geraghty and Miller, 1983). The test was conducted using 90520A as the test-production well, and measuring water levels in the other production weils and in several surrounding monitoring wells. The data obtained from this test indicates that the average transmissivity value of the "Tuscalossa Aquifer" is $79,000 \mathrm{gpd} / \mathrm{ft}$. The results from this test also indicates that the aquifer

2

Prepared for the United States Department of Energy under Contract No. DE-AC09-89SR18035. 
system is generally confined but a small amount of leakance is received from the overlying Tertiary Aquifer System.

\subsection{Contaminants in the Cretaceous Sediments}

As a result of the past surface disposal practices, a plume consisting of dissolved chlorinated solvents, primarily TCE and PCE, exists in the Crowch Branch Aquifer beneath the AM Area of the Savannah River Site. This aquifer is part of the regional hydrologic system that is used both on-site and off-site as a domestic and process water resouree. The present groundwater contamination in this aquifer is flowing in a southwesterly direction towards the interior of the site, away from the site boundary. As documented throughout the A/M Area corrective action program (DOE, 1985) the primary source of the Cretaceous contaminant plume is the past solveat discharges that occurred in the vicinity of the SRTC complex. These contaminants have moved vertically through the M-Area and Lost Lake Aquifers Zones into the Crouch Branch Aquifer Zone. Within the vicinity of the SRTC complex, the Green Clay and Crouch Branch Confining Zones become thin and discomtinuous which results in a locally strong downward head gradient. Near the SRTC complex the gromdruter moves downward through the M-Area and Lost-Lake and upon reaching the Crouch Branch Aquifer tums and flows horizontal beneath the AM Area towards the interior of the site. On a regional scale the Surinuah River acts as a regional groundwater discharge point for the Crouch Branch Aquifer zone in this vieinity.

SRS is currently pursuing an agpressive characterization program to determine the extent of the contamination and the hydrostratigraphy that controls groundwater flow in the Cretaceous Aquifer system as required under Hazadous Weste Permin SCI 890008989 , Condition V.A.3. The principal method being employed in the characteripation program is the retrieval and anatysis of soil cores from the Cretaceous age sediments beneath the AM Area (WSRC, 1993). An integral part of this characterization effort is the collection of bulk soil samples from discrete borizons with subsequent analysis for volatile organics using a headspace analysis procedure developed at the Savannah River Site (Looney et. al., 1993). This sampling technique provides vertical profile of the dissolved contaminant distribution that is not available using conventional monitoring wells. The depth fiscrete data is being used to supplement the monitoring well data to allow investigators to develop a more accurate representation of the distribution of contaminants within the Crouch Branch Aquife. Preliminary analysis of this combined data set indicates that the dissolved contaminants are mignting dowmord across the MCQueen Branch Confining Unit and into the McQueen Branch Aquifer. This analyais indicates that the most likely path of downward migration is the wellbore and gravel peck zones of the AMA Area production well system. This hypothesis is supported with the data obtained from a vertical velocity survey performed in well 905-53A (Marine, 1983). The data from this survey revealed that between 430 feet to 640 feet below grade, the average downward velocity wa 7 feet per minute, or approximately 28 gallons per minute in the 10-inch wellbore. In April of 1985, Geraghty and Miller performed 8 series of tests to determine the condition of production well 905-53A. These tests included a TV camera survey, pecker testing, and a variety of geophysical logging including a flutd velocity $\log$ (Geraghty and Miller, I985). This data supports the hypothesis that during those periods when the production wells are not operating, dissolved contaminants are migrating across the McQueen Branch Confining Unit end into the deeper McQueen Brench Aquifer via the wellbore of production well 905-53A. The analysis of the depth discrete headspace data also indicates that the vertical extent of the dissolved contaminant phume in the Croveh Branch Aquifer is relatively smail when compared to the total thickness of the equifer zone. Examination of the vertical profile of the contaminant distribution indicates that groundwater containing dissolved contuminants is not moving vertically across the McQueen Branch Confining Unit. If this were the situation, the vertical profile obtained from the depth discrete headspace data would indicate contaminants across the entire vertical extent of the Crouch Branch Aquifer Zone.

3

Prepared for the United States Department of Energy under Contract No. DE-AC09-89SR18035. 
Figure \#1: Production Wells, Crouch Branch Monitoring Wells, and Soil Borings in the A/M Area.

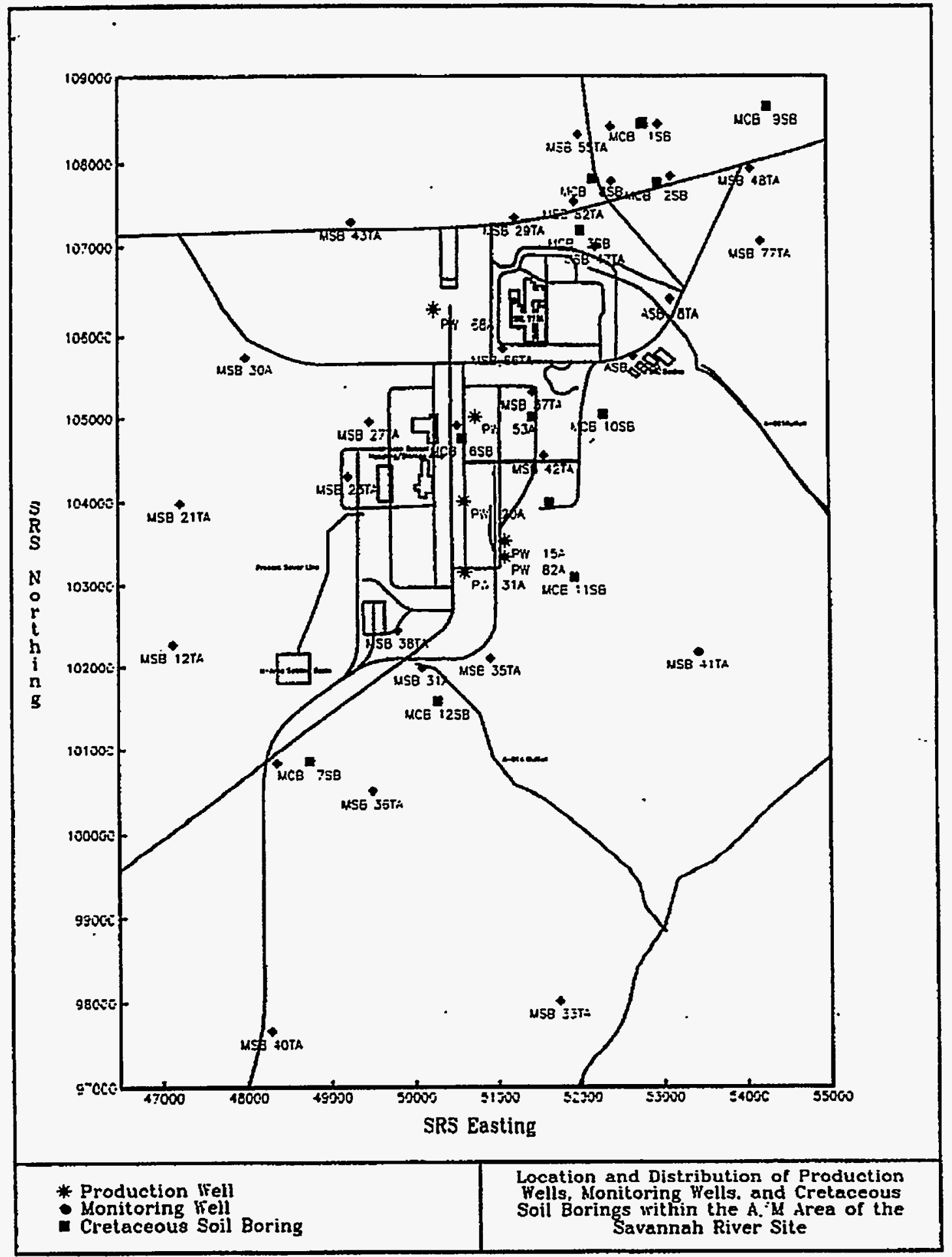

4

Prepared for the United States Department of Energy under Contract No. DE-ACO9-89SR18035. 
Table \#1: Historical Summary of Chlorocarbon Concentrations in A/M Area Production Wells

\begin{tabular}{|c|c|c|c|c|c|c|c|c|c|c|}
\hline \multirow[b]{2}{*}{ Year } & \multicolumn{2}{|c|}{ 305-20L } & \multicolumn{2}{|c|}{$90531 \mathrm{~A}$} & \multicolumn{2}{|c|}{$905-53 \mathrm{~A}$} & \multicolumn{2}{|c|}{$905-68 \mathrm{~A}$} & \multicolumn{2}{|c|}{$905-82 \mathrm{~A}$} \\
\hline & TCE & $\overline{P C E}$ & $\mathrm{TCE}$ & $\overline{\mathrm{PCE}}$ & TCE & PCE & TCE & PCE & TCE & PCE \\
\hline 1982 & $\sim 6$ & na & -5 & na & 10 & na & $<10$ & na & $<10$ & na \\
\hline 1983 & 16 & $<1$ & 7 & $<1$ & 20 & 1 & $<1$ & na & $<1$ & $<1$ \\
\hline 1984 & 38 & $<2$ & $<2$ & $<1$ & 22 & $<2$ & $<2$ & $<2$ & $<1$ & $<1$ \\
\hline 1985 & 52 & $<1$ & 3 & $<1$ & 25 & 3 & $<1$ & $<1$ & $<1$ & $<1$ \\
\hline 1986 & 73 & $<1$ & 4 & $<1$ & 24 & 4 & $<1$ & $<1$ & $<1$ & $<1$ \\
\hline 1987 & 83 & 1.4 & 6 & 2 & 39 & 5 & -1 & $<1$ & $<1$ & $<1$ \\
\hline 1988 & 95 & $<2$ & 3 & $<2$ & 49 & $<5$ & $<1.5$ & $<2$ & $<2$ & $<2$ \\
\hline 1989 & 153 & $<4$ & a & $a$ & 73 & 6 & $<3$ & $<1$ & $<1$ & $<1$ \\
\hline 1990 & 107 & 2 & 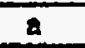 & $a$ & 93 & 7.6 & 2.5 & $<1$ & 0.5 & $\overline{0.6}$ \\
\hline 1991 & 93 & 4.7 & $a$ & $a$ & 108 & 8.6 & 3 & $<2$ & $<5$ & $<2$ \\
\hline 1992 & 76 & $<2$ & 2 & $\mathbf{a}$ & 111 & 10 & $<2$ & $<2$ & $<2$ & $<2$ \\
\hline 1993 & 80 & -4 & $a$ & $a$ & 136 & 17 & $<2$ & $<2$ & $<2$ & $<2$ \\
\hline 1994 & 100 & 2 & $a$ & $a$ & 150 & 10 & ND & $\mathrm{ND}$ & $\mathrm{ND}$ & ND \\
\hline
\end{tabular}

Notes: All Concentration in ug/l (parts per billion)

na - indicates No Data A vailable

ND - None Detected

a - Production Well 905-31A was removed from usage in the A/M Area Production Well System in November of 1988.

5

Prepared for the United States Department of Energy under Contract No. DE-AC09-89SR18035. 


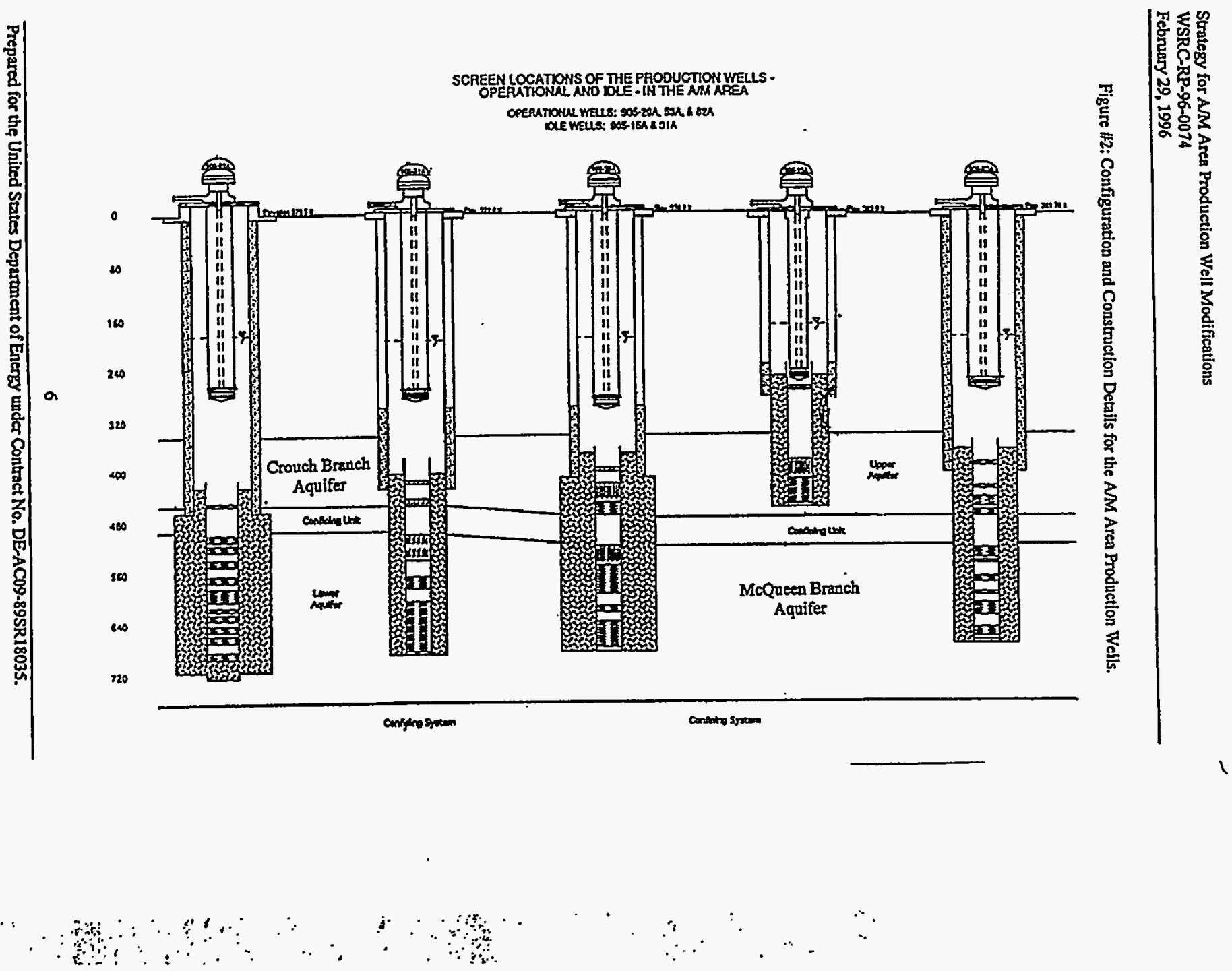


Table \#2: Summary of A/M Area Production Well Construction Details.

\begin{tabular}{|l|r|r|r|r|r|}
\hline & $905-15 \mathrm{~A}$ & $905-20 \mathrm{~A}$ & $905-31 \mathrm{~A}$ & $905-53 \mathrm{~A}$ & $905-82 \mathrm{~A}$ \\
\hline Design Capacity & $500 \mathrm{gpm}$ & $1000 \mathrm{gpm}$ & $1000 \mathrm{gpm}$ & $1500 \mathrm{gpm}$ & $1000 \mathrm{gpm}$ \\
\hline Date of Installation & $4 / 16 / 51$ & $8 / 9 / 51$ & $12 / 4 / 51$ & $6 / 12 / 52$ & $7 / 11 / 77$ \\
\hline Total Depth & $455 \mathrm{ft}$ & $680 \mathrm{ft}$ & $687 \mathrm{ft}$ & $665 \mathrm{ft}$ & $710 \mathrm{ft}$ \\
\hline Surface Casing Depth & $280 \mathrm{ft}$ & $408 \mathrm{ft}$ & $427 \mathrm{ft}$ & $400 \mathrm{ft}$ & $460 \mathrm{ft}$ \\
\hline Surface Casing Dlameter & $18 \mathrm{in}$ & $18 \mathrm{in}$ & $18 \mathrm{in}$ & $20 \mathrm{in}$ & $18 \mathrm{in}$ \\
\hline Surface Casing Bore & $24 \mathrm{in}$ & $24 \mathrm{in}$ & $24 \mathrm{in}$ & $28 \mathrm{in}$ & $22 \mathrm{in}$ \\
\hline Inner Casing Depth & $230-455 \mathrm{ft}$ & $358-680 \mathrm{ft}$ & $377-687 \mathrm{ft}$ & $350-665 \mathrm{ft}$ & $410-695 \mathrm{ft}$ \\
\hline Inner Casing Diameter & $8 \mathrm{in}$ & $8 \mathrm{in}$ & $8 \mathrm{in}$ & $10 \mathrm{in}$ & $10 \mathrm{in}$ \\
\hline Inner Casing Bore & $17 \mathrm{in}$ & $30 \mathrm{in}$ & $17 \mathrm{in}$ & $28 \mathrm{in}$ & $30 \mathrm{in}$ \\
\hline Zone of Gravel Pack & $252-455 \mathrm{ft}$ & $370-680 \mathrm{ft}$ & $397-687 \mathrm{ft}$ & $400-665 \mathrm{ft}$ & $420-710 \mathrm{ft}$ \\
\hline Screen Zones & $265-270 \mathrm{ft}$ & $393-398 \mathrm{ft}$ & $412-417 \mathrm{ft}$ & $385-390 \mathrm{ft}$ & $445-450 \mathrm{ft}$ \\
& $380-410 \mathrm{ft}$ & $417-447 \mathrm{ft}$ & $442-452 \mathrm{ft}$ & $423-428 \mathrm{ft}$ & $496-506 \mathrm{ft}$ \\
& $410-450 \mathrm{ft}$ & $447-467 \mathrm{ft}$ & $497-537 \mathrm{ft}$ & $440-455 \mathrm{ft}$ & $511-521 \mathrm{ft}$ \\
& & $515-545 \mathrm{ft}$ & $562-582 \mathrm{ft}$ & $460-470 \mathrm{ft}$ & $534-544 \mathrm{ft}$ \\
& & $545-590 \mathrm{ft}$ & $602-682 \mathrm{ft}$ & $520-535 \mathrm{ft}$ & $560-570 \mathrm{ft}$ \\
& & $610-620 \mathrm{ft}$ & & $540-545 \mathrm{ft}$ & $585-600 \mathrm{ft}$ \\
& & $635-675 \mathrm{ft}$ & & $565-575 \mathrm{ft}$ & $610-615 \mathrm{ft}$ \\
& & & $590-595 \mathrm{ft}$ & $620-630 \mathrm{ft}$ \\
& & & $608-628 \mathrm{ft}$ & $638-648 \mathrm{ft}$ \\
& & & $645-660 \mathrm{ft}$ & $655-665 \mathrm{ft}$ \\
\hline Total Screen Length & & & & $680-690 \mathrm{ft}$ \\
\hline
\end{tabular}

Note: All Elevations are Referenced to land surface.

7

Prepared for the United States Department of Energy under Contract No. DE-AC09-89SR18035. 
Strategy for A/M Arca Production Well Modifications

WSRC-RP-96-0074

February 29, 1996

Figure \#3: Hydrostratigraphy of the AM Area.

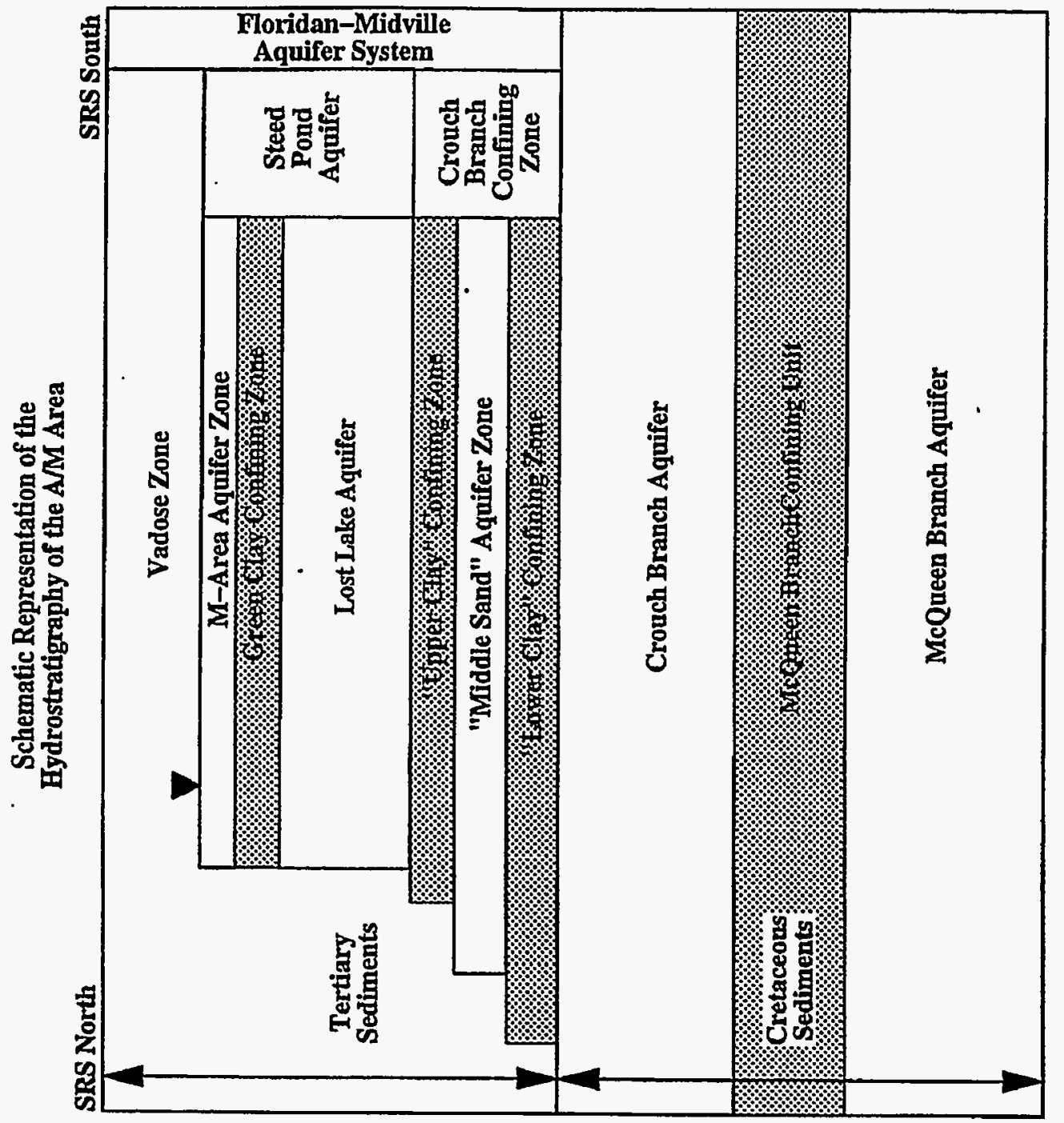




\subsection{Modifications to Production Well System}

In order to prevent the downward migration of the dissolved chlorinated solvents via the production well system, downward flows in the well bore and the gravel pack must be eliminated at the altitude of the McQueen Branch Confining Unit. To address this WSRC plans a two phase program. In the first phase a packer and check valve assembly will be installed inside the wellbore at the altitude of the confining unit. This assembly will prevent downward flow of water from screened intervals in the Crouch Branch Aquifer to screened intervals in the McQueen branch Aquifer. This immediate action should eliminate the high volume of downward flow that exists via the direct connection provided by the wellbore. In the second phase of the program WSRC plans on restoring the competency of the McQueen Branch Confining Unit that has been damaged due to the presence of the production well gravel packs. During the installation process of the packer and check valve assembly WSRC plans several investigative activities to aid in understanding the dynamics of the flow conditions. The data obtained as a result of these activities will aid in developing a feasible course of action for Phase II of the program.

\subsection{Phase / Activities}

During Phase I of this program WSRC plans on instailing a packer and check valve assembly inside the wellbore at the altitude of the McQueen Branch Confining Unit. A schematic of this assembly is shown in Figure \#4. Assemblies similar to this will be installed in production wells $905-20 \mathrm{~A}, 905-31 \mathrm{~A}, 905-53 \mathrm{~A}$ and 905-82A in the $A / M$ Area, these are the production wells that are screened across the McQueen Branch Confining Unit. During this phase of the program several pre- and post-testing activities are planned to ensure that the downward flow via the wellbore is eliminated and to aid in developing plans for Phase $\Pi$ of the program.

\subsubsection{Pre-Installation Testing}

The following pre-installation activities are planned to aid in understanding the dynamics of the flow conditions between the Crouch Branch and the McQueen Branch Aquifers as a result of the production wells. During this phase of the program WSRC plans to perform a down-hole video survey of each wellbore, packer testing of the upper casing, measurement of the vertical flowrate inside each wellbore, and the collection of groundwater samples from specific horizons in each wellbore.

\subsubsection{Downhole Video Survey}

The purpose of this survey is to allow a visual inspection of the internal condition of each wellborc. Since each of the wells involved with this program were installed in the early to mid 1950's the possibility exists for some form of internal wellbore damage. The down-hole video surveys will provide rapid assessment of the internal condition of the wellbore, condition of telescoping joints, and will provide a confirmation on the elevation and type of screen zones. During this test a small video camera will be lowered into the wellbore, recording and documenting these parameters.

\subsubsection{Packer Testing of Upper Casing}

The purpose of this test will be to identify any possible leaks in the upper section of casing that is grouted into the tertiary sediments of the AM Area. During this test a packer will be installed inside the surface casing immediately above the top of the inner casing. The casing will then be filled to the top with water. By observing the steady-state water level inside the casing, any leaks in the upper casing can be identified. This test was performed in 1985 on production well 905-53A (Geraghty and Miller, 1985) and the water level dropped to $90 \mathrm{ft}$. below the land surface before stabilizing, which possibly indicates a leak in the upper casing at this depth. 


\subsubsection{Profile of Vertical Flowrates}

The purpose of this activity is to measure the magnitude of the vertical flowrate between the Crouch Branch and the McQueen Branch Aquifers. This data, coupled with water sample analysis, will be essential in developing both a qualitative understanding of the dynamics of the system as well as providing invaluable data for estimating the amount of contaminant that has moved into the McQueen Branch Aquifer. This bulk estimate regarding the amount of contaminate will be necessary to develop any future actions regarding the McQueen Branch Aquifer. The profile of vertical flowrate will be obtained by lowering a flowmeter inside the wellbore from the standing water level to the bottom of the well. Measurements of the vertical velocity will be made at discrete intervals which will then be coupled with well construction data and discrete wellbore samples to assist researchers in understanding the dynamics of the system.

\subsubsection{Water Sample and Analysis from Specific Horizons}

To compliment the vertical flowrate profile that is to be obtained, water samples are to be collected from above and below specific horizons. These samples will be analyzed for VOCs to assist in developing a qualitative understanding of the flow and transport mechanism involving the production well system. Currently samples are going to be collected at the screen zones that are above and below the McQueen Branch Confining Unit in the Crouch Branch and McQueen Branch Aquifer. Based on the current conceptual model these are the screens that allow entry and exit of the contaminant within the wellbore. The proposed method that will be used to collect these samples will be with a 0.6 liter stainless steel and Teflon sampling bottle (Kemmerer Well Sampler). The sample bottle will be lower to the desired elevation and a messenger will be released to engage the sampling mechanism. Upon retrieval the sample will be analyzed for trichloroethylene (TCE) and tetrachloroethylene (PCE) using the headspace analysis procedure developed at the Savannah River Site (Looney et. al., 1993). One major area of concern in collecting samples from this depth is the loss of contaminant mass through volatilization that may occur due to the pressure changes that the sample will experience. The sealed "pressurized" Kemmerer type sampler was selected as it minimizes this problem as compared to standard well sampling devices. SRS investigators are further examining this effect and consider the proposed technique as a screening technique only intended to assist SRS researchers with data to fully understand the dynamics of the system.

\subsubsection{Installation Details}

Once the pre-installation testing is completed a packer and check valve assembly will be installed in the wellbore. SRS personnel are currently examining two installation options. In both cases the downward flow that exists inside of the wellbore will be eliminated via a commercially available check-valve assembly that will be installed at the altitude of the McQueen Branch Confining Unit. In addition, additional inflatable packers will be installed in those production wells that have multiple screen zones within the Crouch Branch Aquifer. The purpose of these additional packers will be to prevent the vertical migration of dissolved contaminants within the Crouch Branch Aquifer while preserving the "passive" remediation that occurs when the production wells are operated (Haselow, 1989). The production wells that the additional packers will be instalied in are 905-20A, 905-31A, and 905-53A. The first, and preferred, installation option is to hang the entire packer assembly from the bottom of the existing pump assembly of each production well. This installation method would ensure the proper placement of the packer assembly and would minimize the equipment that has to pass by the pump assembly. However, this method would require that the packer and check valve assembly be removed every time that the pump is removed for maintenance. The second method being examined is the installation of the entire packer assembly via cables that would be attached at the land surface. This installation method would not require the removal of the packer and check valve assembly every time that the pump assembly is removed. This installation method does increase the amount of equipment that has to pass by the pump assembly. SRS personnel are 
currently examining the feasibility of each of these options, taking into account conventional packer installation techniques, material limits, and the appropriate operational and maintenance considerations.

\subsubsection{Production Well 905-15A}

The casing of production well 905-15A does not penetrate the McQueen Branch Confining Unit so no packers are check valve assemblies are required.

\subsubsection{Production Well 905-20A}

In production well 905-20A one (1) packer and check valve assembly will be installed at a depth of approximately 500 feet below the land surface. In addition a packer will be installed in the slotted pipe section that is located 417 to 447 feet below the land surface. This packer assembly will be positioned in the lower portion of this screen section so that the screen section that lies along the plume horizon will be available for "passive" remediation. Installation of this packer assembly will isolate the wire-wrap screen section that lies between 447 and 467 feet below the land surface.

\subsubsection{Production Well 905-31A}

In production well 905-31A one (1) packer and check valve assembly will be installed at a depth of approximately 480 feet below the land surface. In addition a packer will be installed in the blank section that is located between 417 to 442 feet below the land surface. This packer assembly will isolate the slotted screen section that lies between $\mathbf{4 4 2}$ and 452 feet below the land surface.

\subsubsection{Production Well 905-53A}

In production well 905-53A one (1) packer and check valve assembly will be installed at a depth of approximately 500 feet below the land surface. In addition a packer will be installed in the blank section that is located between 428 to 440 feet below the land surface. This packer assembly will isolate the two slotted screen section that lies between 440 and 455 feet and between 460 and 470 feet below the land surface.

\subsubsection{Production Well 905-82A}

In production well 905-82A one (1) packer and check valve assembly will be installed at a depth of approximately 480 feet below the land surface. No additional packer is needed in this production well since the only screen that is located within the Crouch Branch Aquifer is a five ( 5 ) foot section that is located 445 to 450 feet below the land surface.

\subsubsection{Post-Installation Testing}

Several activities are planned to ensure that the downward flow via the wellbore is eliminated after each of the packer and check valve assemblies are installed. In addition performance tests will be completed to determine what influence each of the installed assemblies has on the production capacity of each of the wells.

\subsubsection{Vertical Flowrate above Check Valve}

The purpose of this activity will be to measure the magnitude of the vertical flowrate above the installed check valve assembly to verify operation of the valve in halting of the downward vertical flow into the lower McQueen Branch Aquifer. The profile above the McQueen Branch Confining Unit will be obtained by lowering a flowmeter inside the wellbore from the standing water level to the top of the check valve

Prepared for the United States Department of Energy under Contract No. DE-AC09-89SR18035. 
assembly. Measurements of the vertical flowrate/velocity will be made at discrete intervals to the maximum depth possible. These results will be compared to the results obtained in during the preinstallation testing.

\subsubsection{Production Capacify Tests}

Upon the installation each packer and check valve assembly the Power Department will perform a routine capacity performance test on the production well. This test will allow Power Department personnel to identify any lost performance associated with the installation of the packer and check valve assemblies. This information is necessary for water resource management in the A/M Area.

\subsubsection{Periodic Maintenance of Packer Assemblies}

The packers that are currently being proposed for installation are inflatable type packers. For the most part these devices are maintenance free. The only long-term consideration is maintaining the necessary inflation pressure in the packer. To accommodate this an inflation tube and pressure gauge will be permanently installed from each packer to the land surface. This assembly will allow the SRS Power Department to monitor the packer inflation pressure as part of their routine operational procedures. Packer inflation pressures will be maintained based upon vendor recommendations.

\subsection{Phase II Activities}

The specific activities in Phase II of this program are currently being investigated to develop the most feasible and economic path forward. The second phase of the program will address the small amount of contaminant mass that is moving downward through the continuous gravel pack of the production welis. The investigative data obtained during Phase I of this program will be beneficial for developing plans and appropriate actions for the Phase II activities. Site personnel are currently evaluating various options, i.e. casing perforation with grout injection or partial well abandonment, to eliminate the downward flow in the gravel pack at the altitude of the MCQueen Branch Confining Zone. WSRC Power Department is currently incorporating a Block/Squeeze technique in the F/H Area of the site in the abandonment program of other production wells. This is a casing perforation and grout injection technique designed to restore the competency of breached confining units. Tho technique injects low permeability grout into the formation and gravel pack at the altitude of the confining unit via casing perforations. Once the injection is completed, the well typically has to be rebored and the casing polished at the altitude of the perforations. If this technique is adopted in the $A M$ Area, the packer and check valve assemblies would be temporarily removed and the Block Squeeze technique would be applied at the altitude of the McQueen Branch Contining Unit.

\subsection{Proposed Schedule}

WSRC is currently planning to start the presented activities in mid-March. The completion rate of the presented activities in Phase I are expected to occur at a rate of one well per month. Concurrent with this activity WSRC plans to continue alternative investigations for addressing the downward flow in the gravel pack zone. 
Figure \#4: Schematic Representation of a Typical Packer and Check Valve Assembly.

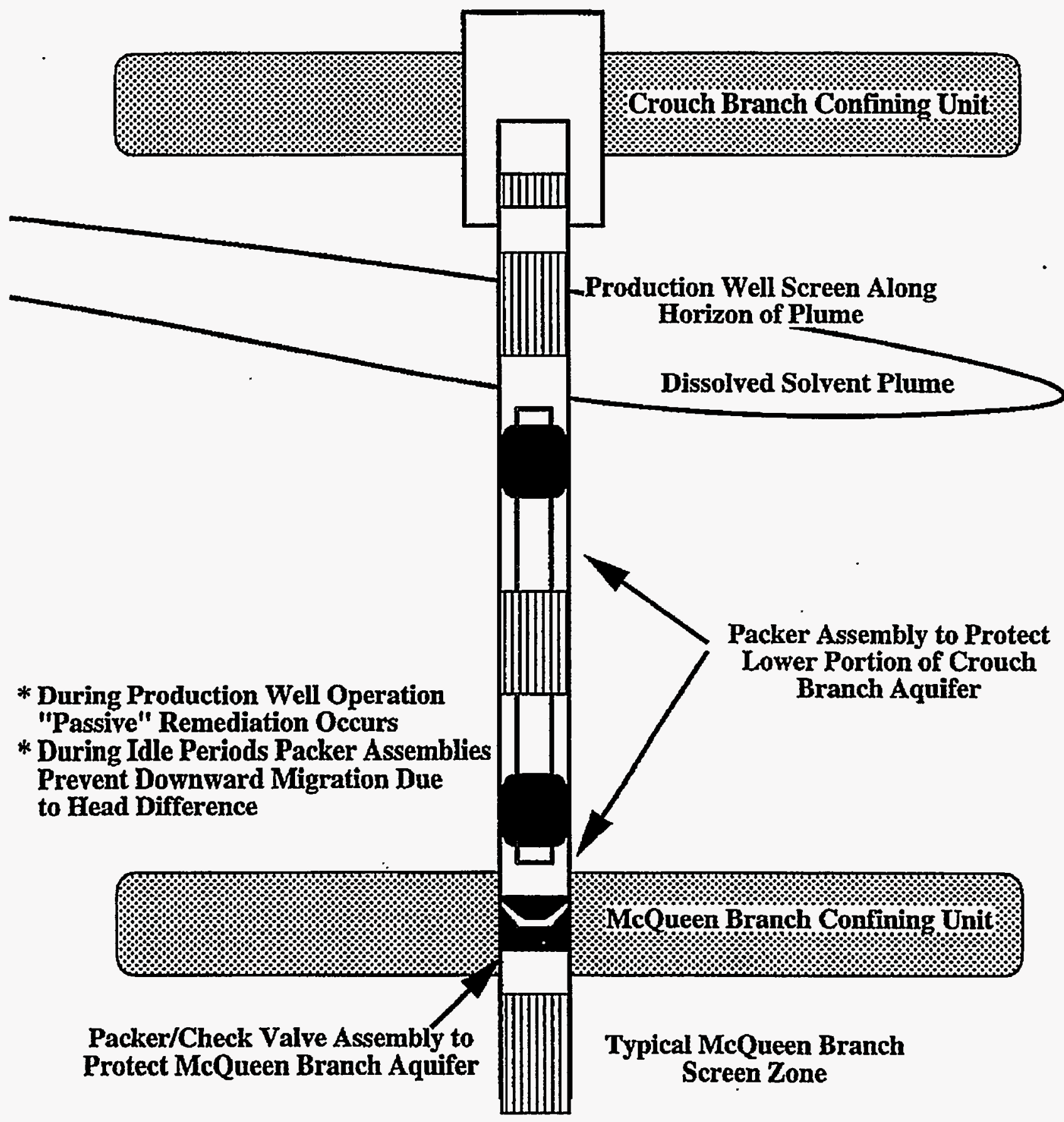




\subsection{Long Term Strategies for Cretaceous Aquifers}

The results of the recent characterization of the Crouch Branch Aquifer in the A/M Area are currently being examined to address remediation options. The remediation options currently being examined include: pump and treat, continued "passive" remediation, conversion of existing production wells to recovery wells, and air injection with vertical recirculation. Of these technologies the traditional pump and treat technology is least favorable due to the relatively great depth of the Crouch Branch Aquifer, typically greater that 300 feet below the land surface, combined with the high transmissivity of the aquifer. Both of these attributes combine to produce a relatively expensive remediation option when compared with current operational costs for the tertiary aquifers in the $A / M$ Area. The existing process water production wells, 905-20A and 905-53A, provide "passive" remediation for a portion of the contaminant plume within the A/M Area. This "passive" remediation system is contingent on continued process water demands within the A/M Area. SRS is currently exploring the possibility of retrofitting these process water wells into a remediation system. To this extent partial well abandonment is being examined in which that portion of the well within the plume horizon would be developed into a remediation system. Potentials for this system include conventional pump and treat technologies or the incorporation of more innovative technologies such as air injection with vertical recirculation.

In the interim, five recovery wells are being installed in the upper tertiary aquifer in the vicinity of the Savannah River Technology Center to reduce the source of solvents into the Crouch Branch Aquifer. Previous analysis (Jackson and Aleman, 1995) indicate that these wells provide plume capture and control from this source zone within the Northem Sector of the $A / M$ Arez. The lack of a northward natural groundwater flow gradient, combined with the zone of capture of this system, precludes any significant potential for the migration and spread of groundwater contamination beyond the northern site boundary near the SRTC complex.

\subsection{Summary}

In order to reduce the amount of dissolved chlorinated solvents that are being transported to the McQueen Branch Aquifer a two phase program is planned. In Phase I of the program a commercially available intlatable packer and check valve assembly will be installed inside the wellbore of the $A$ /M Area production wells at the altitude of the McQueen Branch Confining Unit. During Phase II of the program the small amount of contaminant mass that is moving downward through the continuous gravel pack is to be addressed. Investigative data obtained during Phase I of this program will be beneficial for developing plans and appropriate actions for these activities. The implementation rate of one (1) well per month for the Phase I activities will eliminate the contaminants that are moving downward across the McQueen Branch Confining Unit via the wellbore.

\subsection{References}

Amett, M.W., L.K. Karapatakis, A.R. Mamatey and J.L. Todd (1992). "Savannah River Site Environmental Report for 1991 (U)," WSRC-IM-92-186, Westinghouse Savannah River Company, Aiken, South Carolina 29808.

Arnett, M.W. (1993). "Savannah River Site Environmental Report for 1992 (U)," WSRC-TR-93-075, Westinghouse Savannah River Company, Aiken, South Carolina 29808.

Amett, M.W. (1994). "Savannah River Site Environmental Report for 1993 (U)," WSRC-TR-94-075, Westinghouse Savannah River Company, Aiken, South Carolina 29808.

Amett, M.W. (1995). "Savannah River Site Environmental Report for 1994 (U)," WSRC-TR-95-075, Westinghouse Savannah River Company, Aiken, South Carolina 29808. 
Ashley, C., P.C. Padezanin and C.C. Zeigler (1984a). "Environmental Monitoring at the Savannah River Plant: Annual Report for 1982," DPSPU 83-302, Issued June 1984, Health Protection Department, Savannah River Plant, E.I. du Pont de Nemours \& Company, Aiken, South Carolina 29808.

Ashley, C., P.C. Padezanin and C.C. Zeigler (1984b). "Environmental Monitoring at the Savarnah River Plant: Annual Report for 1983," DPSPU 84-302, Issued June 1984, Health Protection Department, Savannah River Plant, E.I. du Pont de Nemours \& Company, Aiken, South Carolina 29808.

Cummins, C.C., D.K. Martin and J.L. Todd (1989). "Savannah River Site Environmental Report for 1989 (U)," WSRC-IM-90-60, Westinghouse Savannah River Company, Aiken, South Carolina 29808.

Cummins, C.C., D.K. Martin and J.L. Todd (1991). "Savannah River Site Environmental Report for 1990 (U)," WSRC-IM-91-28, Westinghouse Savannah River Company, Aiken, South Carolina 29808.

Davis, H.A., D.K. Martin and J.L. Todd (1988). "Savannah River Site Environmental Report for 1988 (U)," WSRC-RP-89-59-1, Westinghouse Savannah River Company, Aiken, South Carolina 29808.

Department of Energy (1987). "Savannah River Site Hazardous Waster Permit," SCl 890008989. September 1987, Aiken, South Carolina 29808.

Haselow, John S. (1989). "Numerical Simulation of Groundwater Flow to the Process Water Wells at the AM Area," WSRC-TR-90-1025, Westinghouse Savannah River Company, Aiken, South Carolina 29808.

Horvath, J.G. (1988). "Black Creek Investigation Program," DPSP 88-1046, Issued June 1988, E.I. du Pont de Nemours \& Company, Savannah River Plant, Aiken, South Carolina 29808.

Jackson, Dennis G. and Sebastian E. Aleman (1985). "Three-Dimensional Zone of Capture Analysis for the A/M Area," WSRC-RP-95-0843, Westinghouse Savannah River Company, Aiken, South Carolina 29808.

Lewis, S.E. and R.K. Aadland (1994). "Hydrogeologic Setting of A/M Area: Framework for Groundwater Transport (U)," WSRC-92-355, Issued March 1994, Westinghouse Savannah River Company, Aiken, South Carolina 29808.

Looney, Brian B., John S. Haselow, Mariesia A. Keenan, Robert S. Van Pelt, Carol A. Eddy-Dilek, Joseph Rossabi, and John L. Simmons (1993). "Analysis of Volatile Organic Compounds in A/M Area Crouch Branch (Cretaceous) Aquifer Characterization Samples: 1993 (U)," WSRC-RP-93-1545, Issued December 6, 1993, Westinghouse Savannah River Company, Aiken, South Carolina 29808.

Looney, Brian B., Carol A. Eddy-Dilek, and W.R. Sims (1993). "Evaluation of Headspace Method for Volitile Constituents in Soils and Sediments," Measuring and Interpreting VOCs in Soils: State of the Art and Research Needs, United States Environmental Protection Agency, Environmental Monitoring Systems Laboratory, Las Vegas, Nevada 89193.

Marine, I.W. (1983). "Summary of Evidence for and Against Chlorocarbon Contamination of the Tuscaloosa Formation in the A/M Area," Savannah River Plant Inter-Office Correspondence dated December 19, 1983, Savannah River Plant, E.I. du Pont de Nemours \& Company, Aiken, South Caroline 29808.

Mikol, S.C., L.T. Burkhalter, J.L. Todd and D.K. Martin (1987). "U.S. Department of Energy Savannah River Plant Environmental Report for 1987," DPSPU 88-30-1, Health Protection Department, Savannah River Plant, E.I. du Pont de Nemours \& Company, Aiken, South Carolina 29808.

Van Pelt, Robert S., John S. Haselow, James E. Jordan, Sharon E. Lewis, and Thomas L. Lott (1993). "Crouch Branch Aquifer Study, A/M Area Recent Findings, Observations, and Recommendations (U)," WSRC-RP-93-1214, Issued September 10, 1993, Westinghouse Savannah River Company, Aiken, South Carolina 29808. 
WSRC (1993). "ANM Area Crouch Branch (Cretaceous) Aquifer Characterization - Phase I: Soil Coring Report (U), WSRC-RP-93-1241, Issued September 1993, Westinghouse Savannah River Company, Aiken, South Carolina 29808.

Zeigler, C.C., I. B. Lawerence, and W. E. O'Rear (1985). "Environmental Monitoring at the Savannah River Plant: Annual Report for 1984," DPSPU 85-30-2, Issued June 1985, Health Protection Department, Savannah River Plant, E.I. du Pont de Nemours \& Company, Aiken, South Carolina 29808.

Zeigler, C.C., I. B. Lawerence, and E. M. Heath (1986). “U.S. Department of Energy Savannah River Plant Environmental Report for 1985," DPSPU 86-30-1, Health Protection Department, Savannah River Plant, E.I. du Pont de Nemours \& Company, Aiken, South Carolina 29808.

Zeigler, C.C., E. M. Heath, L.B. Taus, J.L. Todd (1987). “U.S. Department of Energy Savannah River Plant Environmental Report for 1986," DPSPU 87-30-1, Health Protection Department, Savannah River Plant, E.l. du Pont de Nemours \& Company, Aiken, South Carolina 29808. 